\title{
The Fate of Soil Resource in Response to Global Warming
}

\author{
Abdeta Jembere Ebsa* \\ Department of Natural Resource Management, Wolkite University, Ethiopia
}

Submission: January 07, 2019; Published: January 23, 2019

*Corresponding author: Abdeta Jembere Ebsa, Department of Natural Resource Management, Wolkite University, P.O Box: 07, Wolkite, Ethiopia

\begin{abstract}
It is apparent that global warming, from which all natures suffer, has just pressed and is increasing in alarming rate. This review, thus, aimed at dealing with the consequences of increment of atmospheric temperature on soil physicochemical, biological and morphological responses. The review revealed that soil shares the detrimental effects of global warming in a way that there is direct relationship between atmospheric temperature and soil temperature. Hence, any change on atmospheric temperature as a result of global warming affects soil organisms. Similarly, soil structure, porosity, infiltration and moisture content, are destroyed by the absence of microbes and due to intensive rain drops. Besides, soil biochemical reaction terminates beyond its optimum temperature rage. Global warming, as a result, entirely disrupts soil functions, which calls for mitigation and adaptation schemes.
\end{abstract}

Keywords: Soil; Carbon dioxide; Temperature; Atmosphere

\section{Introduction}

Global warming is an increase in earth's annually averaged air temperature near the surface [1]. Recent scientific evidence shows that release of greenhouse to the atmosphere and posing the earth's temperature called global warming. Carbon dioxide $\left(\mathrm{CO}_{2}\right)$ is among greenhouse gases that traps temperature and cause the atmosphere warm beyond optimum level (International panel on climate change [2].

IPCC (2) projected that in 2050s, the temperature increment will be $2.4{ }^{\circ} \mathrm{C}$ and $2.0{ }^{\circ} \mathrm{C}$ for the lower and highest scenarios respectively whereas, in 2080 s the maximum temperature will be increased by $3.8{ }^{\circ} \mathrm{C}$ and $3.2{ }^{\circ} \mathrm{C}$. The ranges of these estimates arise from the use of models with differing sensitivity to greenhouse gas concentrations. Likewise, Yakob [3] reported that maximum temperature was projected to $1.2{ }^{\circ} \mathrm{C}$ in $2020 \mathrm{~s}$ on Anjeni Watershed in Blue Nile basin in Ethiopia.

Natural resource, on which entire lives on the earth depend, is the vulnerable resource that receives the detrimental effects of this climate change, which in turn brings ecological disturbances (www.environment.about.com/od/effectonnaturalresources). Hence soil is the end product of the influence of the climate, relief, organisms, parent materials and time [4], any change manifested on these factors can indirectly affect the composition and properties of the soil.

According to Field et al. [5] finding, changes in soil moisture and soil temperature influence ecosystem processes viz-aviz nutrient cycling, primary productivity, plant survival and recruitment in terrestrial ecosystems. Soil aggregate-destruction by raindrops, surface runoff and filtrating water, and changes in the vegetation pattern and land use practices are also the consequences of climate change Várallyay [6].

Soil bio-physicochemical properties are therefore highly influenced by soil moisture [7]. Besides, Delgado et al. [8] reported that there is a close relationship between climate change, limited global water and soil resources, population growth, and food security. As climate change impacts the world's soil and water resources, it threatens food production and/or food production potential. As impaired ecosystem, soil cannot normally function to support and provide good and services [8]. Thus, the objective of this paper was to review the correlation between air and soil temperature and then soil physicochemical, biological and morphological responses to global warming.

\section{The Linear Relationship between Soil and Atmospheric Temperature}

The response of soil temperatures to changes in air temperature strongly depends on the temporal distribution, depth, and density of the snowpack during the winter [9]. Fluctuation of air temperature attributes to small changes in the size of $\mathrm{CO}_{2}$ flux. The soil $\mathrm{CO}_{2}$ emission fluxes thereon increased $86.86 \%$ with the air temperature increasing $3.74^{\circ} \mathrm{C}$ [10]. As Hunt et al. [11] demonstrated on 3 sites in different region across USA, there were strong relationships between the average daily air temperatures and observed daily soil temperatures at the $10 \mathrm{~cm}$ depth for all 7 model development sites; $\mathrm{R}^{2}$ values ranged from 0.86 to 0.97 . 
Ahmad \& Rasul [12] have also modeled proportional the relationship between air temperature and soil temperature in Pakistan. They also depicted that there was significant, greater than $85 \%$, positive correlation between soil and air temperature in all scenarios (Figure 1). According to Hunt et al. [10], in Montana region, one unit increase in air temperature will increase soil temperature by 4.87 units.

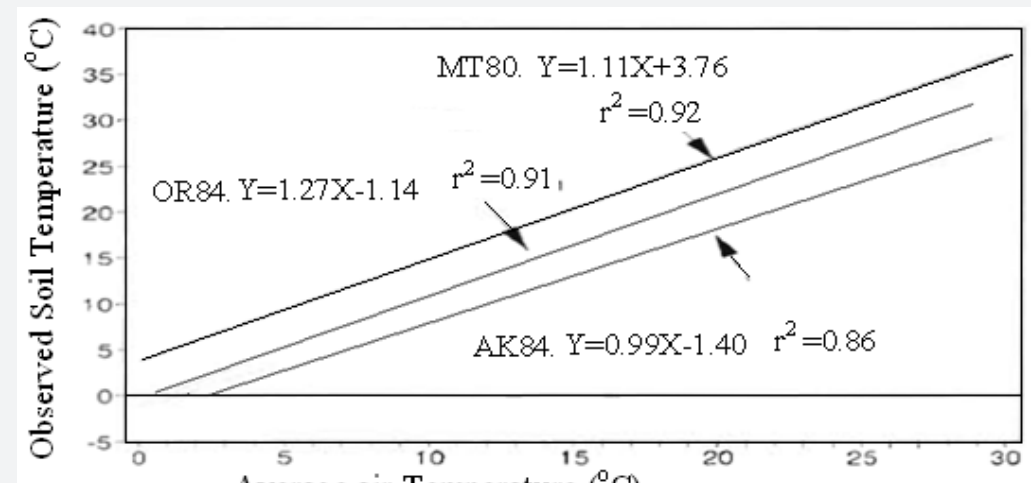

Average air Temperature $\left({ }^{\circ} \mathrm{C}\right)$

Figure 1: Relationships between air temperatures (“C) after 1.1-day running averages and soil temperatures ('C) at $10 \mathrm{~cm}$ depth for the 3 model-development sites representing different climatic regions in the U.S. MT80=Montana, AK8=Alaska and OR84=Oregon. (Source: Hunt et al. [10])

\section{Effects Global Warming on Soil Properties}

\section{Impacts of global warming on soil biological properties}

There great diversity of soil organisms many of which have similar functions and general decomposition function, are disrupted by climate change [13]. Increased microbial activity due to optimum temperature produces greater amounts of polysaccharides and other soil stabilizers. However, these microorganisms' population, structure and composition are inhibited by the anticipated extreme temperature [6].

Adverse environmental conditions, mainly elevated soil temperature is likely to facilitate fungi to survive better, since they rely on more aerobic conditions [14]. Moreover, filamentous nature and lower $\mathrm{N}$ content of fungi [15] makes the tolerant to higher soil temperature and drying [16]. Thus, beyond certain threshold warming may enhance fungal contribution to the microbial community [17].

The effects of increased atmospheric $\mathrm{CO}_{2}$ concentration on bacterial biomass, richness, and community composition have been shown to vary between ecosystems, resulting in no common trends, except a 3.5 fold decrease in the relative abundance of Acidobacteria group 1 bacteria [18]. As a result, increased temperature often affects recalcitrant soil organic matter more than labile soil organic matter [18], which attributes to increased warming of passing the critical activation energy (Ea) needed for decomposing resistant compounds [19].

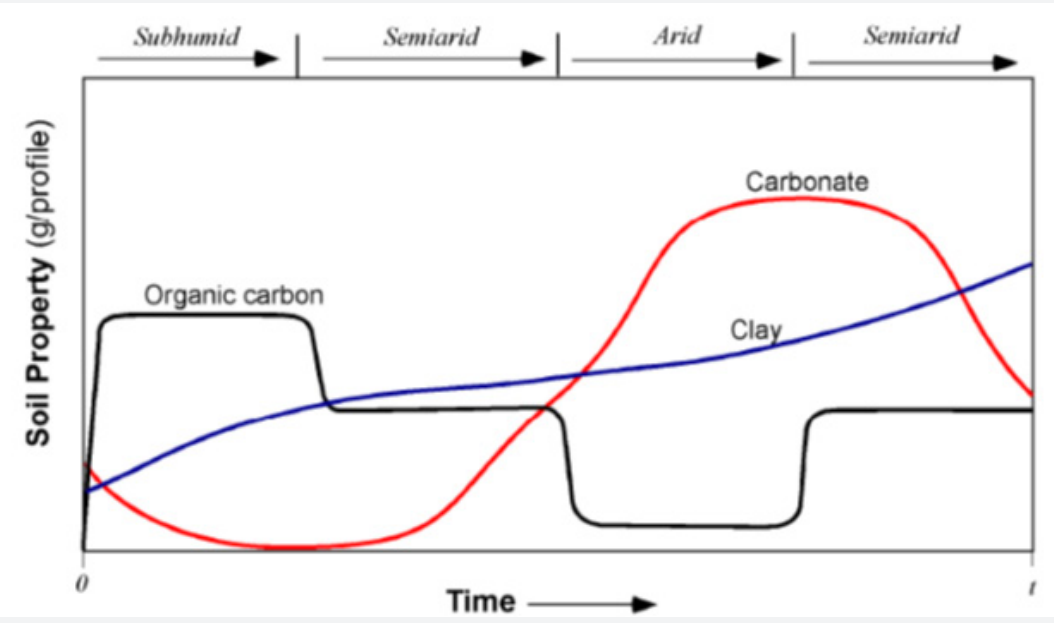

Figure 2: Hypothetical variations of three soil properties with time and climate change. (Source: Monger, [25]).

Additionally, long-term warming could also induce changes in plant species composition, which can significantly affect soil microbial production of extracellular enzyme activity.
Changes in extracellular enzyme activities and production may influence which compounds are most effectively utilized by soil microorganisms under warming conditions and potentially 
result in altered nutrient pools [20]. These intermingling effects eventually result in disruption of soil microbial structure, biomass and function (Figure 2).

According to Schimel \& Gulledge [21], populations of cellulolytic and ligninolytic fungi reduction may impose a decrease in litter decomposition greater than would be predicted by considering only the changes in soil and litter moisture in areas where episodic drying and rewetting of soil attributed to climate change becomes more severe.

\section{Impacts of global warming soil on chemical properties}

Even though it accelerates soil chemical reaction, soil temperature impairs soil chemical composition and/or soil fertility at its level [22]. Climate change can also influence acid sulphate soils production via sea level rise and via changes to rainfall incidence and flood flows. Therefore, $\mathrm{pH}$ values may temporarily reach 2.5 to 3.5 and a small part of the clay fraction may be decomposed as indicated under processes in soils, above. This then buffers the $\mathrm{pH}$ generally between 3.5 and 4 in the long run [23].

Fluctuation of temperature increase freeze-thaw cycle, which result increase in exchangeable NH4-N and decreased exchangeable K. This creates movement of water along with gradients of nutrients and thermal conductivity and effects nutrient availability, cation exchange properties, soil weathering, and biological activity [24]. Enhanced in soil water movement leads to active and increased groundwater discharge and further depletes soil nutrients [25].

Moreover, Groffman et al. depicted that if ongoing global warming continues, freeze-thaw cycles in highland soils can significantly influence the availability of $\mathrm{Zn}$, after freeze-thaw cycles, the highland soils have more availability for $\mathrm{Zn}$ than without freeze-thaw cycles.

Table 1: Mean values $( \pm \mathrm{SE})$ of the soil biochemical variables recorded in the three experimental treatments T1-3.

\begin{tabular}{|c|c|c|c|}
\hline & T1 & T2 & T3 \\
\hline MBC $\left(\mathrm{mg} \mathrm{g}^{-1}\right)$ & $1.930 \pm 0.270$ & $1.970 \pm 0.170$ & $2.215 \pm 0.271$ \\
\hline MBN $\left(\mathrm{mg} \mathrm{g}^{-1}\right)$ & $0.365 \pm 0.044$ & $0.203 \pm 0.027$ & $0.124 \pm 0.021$ \\
\hline Organic $\mathrm{N}^{\left(\mathrm{mg} \mathrm{g}^{-1}\right)}$ & $4.395 \pm 0.323$ & $3.955 \pm 0.231$ & $3.055 \pm 0.168$ \\
\hline $\mathrm{NH}_{4}+\left(\mathrm{mg} \mathrm{g}^{-1}\right)$ & $57.500 \pm 12.047$ & $64.300 \pm 14.256$ & $47.420 \pm 8.103$ \\
\hline $\mathrm{NO}_{3}^{-}$ & $64.700 \pm 13.199$ & $69.400 \pm 14.485$ & $52.710 \pm 8.219$ \\
\hline
\end{tabular}

Source: Monokrousos et al. [15]; MBC=microbial biomass of $\mathrm{C}$ $\mathrm{MBN}=$ biomass of $\mathrm{N}, \mathrm{SE}=$ standard error.

Monokrousos et al. [15] showed that the concentration of microbial biomass $\mathrm{C}(\mathrm{MBC})$, biomass $\mathrm{N}$, organic $\mathrm{N} \mathrm{NH}_{4}{ }^{+}$and $\mathrm{NO}^{-3}$ by using three temperature regimes, increase in temperature increased $\mathrm{MBC}$ rationalized by increase in decomposing microbial activities in response to the temperature (Table 1).

Monger [26] concluded that, soil organic carbon is a soil property that responds to climate change more quickly than the others. While, pedogenic carbonate and clay content responds less rapidly to climate and has a more gradual increase with time during wetter periods and finer soil particle accumulation during drier periods.

Soils with a thermic or hyperthermic temperature regime experiencing accelerated rates of mineral weathering and decomposition may contribute low-activity clays and low organic matter [27]. Likewise, soil organic carbon is composed of a wide range of organic matters having various decomposition rates derived from, soil temperature and moisture, diversity and abundance of organisms, association with soil minerals and degree of aggregation [28].

\section{Impacts of global warming on soil physical properties}

As climate temperature is altered, the rainfall pattern and intensity shift from its initial condition to unconsumed state. One of the predicted effects of climate change is an increase in the frequency of high-intensity storms, which would in turn increase rainfall erosivity. Feddema and Freire [29] predicted that average temperatures, continent wide, for the 2010-2039 periods are expected to increase by $1.33^{\circ} \mathrm{C}$, resulting in a $119 \mathrm{~mm}$ increase in the potential evapotranspiration rate in Africa. At the same time, precipitation is expected to decrease by $30 \mathrm{~mm}$ continent wide, resulting in net drying soil moisture.

Table 2: Clay content (40inch depth) of idealized soil derived from granites and gneisses for selected moisture and temperature values. (Constancy of other soil-forming factors assumed).

\begin{tabular}{|c|c|c|c|c|c|}
\hline \multirow{7}{*}{ 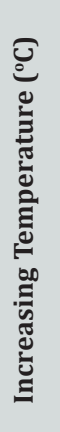 } & \multicolumn{5}{|c|}{ Increasing Moisture (mm) } \\
\hline & & 100 & 200 & 300 & 400 \\
\hline & $\mathbf{0}$ & $1.1 \%$ clay & $2.3 \%$ clay & $3.4 \%$ clay & $4.6 \%$ clay \\
\hline & 5 & $2.3 \%$ clay & $4.6 \%$ clay & $6.9 \%$ clay & $9.2 \%$ clay \\
\hline & 10 & $4.6 \%$ clay & $9.2 \%$ clay & $\begin{array}{c}13.9 \% \\
\text { clay }\end{array}$ & $\begin{array}{c}18.5 \% \\
\text { clay }\end{array}$ \\
\hline & 15 & $9.3 \%$ clay & $\begin{array}{c}18.6 \% \\
\text { clay }\end{array}$ & $\begin{array}{c}27.9 \% \\
\text { clay }\end{array}$ & $\begin{array}{c}37.2 \% \\
\text { clay }\end{array}$ \\
\hline & 20 & $\begin{array}{c}18.8 \% \\
\text { clay }\end{array}$ & $\begin{array}{c}37.5 \% \\
\text { clay }\end{array}$ & $\begin{array}{c}56.3 \% \\
\text { clay }\end{array}$ & $\begin{array}{c}(75.0 \%) \\
\text { clay }\end{array}$ \\
\hline
\end{tabular}

Source: Jenny [4].

The influence of climate change on soil structure type, spatial arrangement and stability of soil aggregates is a more complex process. The apparent detrimental effects of climate change are the aggregate-destructing role of raindrops, surface runoff and filtrating water, especially during heavy rains, thunderstorms and even rain bombs, the increasing hazard, frequency and intensity of which are characteristic features of climate change [30-32]. The indirect influences are caused by changes in the vegetation pattern and land use practices [6]. Accordingly, Jenny [4] illustrated soils developed in regions of high temperature tend to be high in clay but low in organic matter (Table 2).

Increase in temperature in hot and dry conditions results in decrease in precipitation. The decrease in atmospheric precipitation will in turn result in a decrease in water infiltration and soil water holding capacity and plant available water. 
Consequently, surface runoff in hilly lands with undulating surfaces causes water erosion hazard and will increase evaporation losses [6].

According to Monger [26], soils erosion has stripped away the $\mathrm{A}$ and $\mathrm{B}$ horizons of the soils and exposed underlying calcic horizons. As a result of the calcic horizons are brought into the shallow, more intense weathering zone of increased biologic activity above the depth where pedogenic carbonate normally forms, the possibility arises that such exhumed carbonates are active sources of $\mathrm{CO}_{2}$ emissions.

\section{Conclusion}

Different anthropogenic activities and natural processes contributed $\mathrm{CO}_{2}$ to atmosphere, which is alarming global temperature. Consequently, different recent research results predicted that the atmospheric temperature would reach at the point beyond environmental temperature tolerance in nearby future. The temperatures, above its optimum point, impose detrimental effects on all systems with which it openly exchanges matter and energy take place. Soil is among the system that shares all consequences attributed to the climate change.

Different scientists devoted to elaborating that there was proportional linear correlation between atmospheric temperature and soil temperature. In response to the climate change, soil biota, soil physicochemical properties and soil morphology will get altered. To some extent, increase in soil temperature accelerates chemical reaction and biological activities that take place within the soil system. Nevertheless, the consequences of increased global temperature above threshold level brings the disruption of soil function that result in soil fertility loss in terms of biological, chemical, physical and morphological aspects. This, in turn, hinder the goods and services provided by soil on which all organisms rely.

\section{Prospects (future line of work)}

Even though atmospheric and soil temperature are positively correlated, the strength of the correlation $\left(\mathrm{R}^{2}\right)$ between soil and air temperature varies according to the soil type, soil color, land use systems and other environmental conditions. Therefore, there is a need to study soils of all agro ecology response to atmospheric temperature fluctuation. Besides, concerned soil scientists should engage in and collaborate with natural resource managers to alleviate the effects of global warming on our soils.

\section{References}

1. (2014) NOAA Climate.gov.

2. IPCC (2007) Climate change: The physical science basis. Intergovernmental Panel on Climate Change. Geneva, Switzerland.

3. Yakob M (2009) Climate change impact assessment on soil water availability and crop yield in Anjeni watershed Blue Nile basin. MSc. Thesis: Arbamich University, Ethiopia.

4. Jenny H (2005) Factors of soil formation; a system of quantitative pedology. Mineola, New York, USA.
5. Field CB, Chapin FS, Matson PA, Mooney HA (1992) Responses of terrestrial ecosystems to the changing atmosphere: a resource-based approach. Annual Review of Ecology and Systematic 23: 201-236.

6. Várallyay G (2010) The impact of climate change on soils and on their water management. Agronomy Research 8 (II): 385-396.

7. Brinkman R, Sombroek G (1993) The effects of global climate change on soil conditions in relation to plant growth and food production:paper for expert consultation. FAO, Rome.

8. Delgado JA, Groffman PM, Nearing MA, Goddard T, Reicosky D, et al. (2011) Conservation practices to mitigate and adapt to climate change. Journal of Soil and Water Conservation 66(4): 118A-129A.

9. Lawrence D, Slater A (2010) The contribution of snow condition trends to future ground climate. Clim Dynam 34(7-8): 969-981.

10. Lu X Fan J Yan Y Wang X (2013) Responses of soil CO2 fluxes to shortterm experimental warming in Alpine Steppe ecosystem Northern Tibet. PLoS One 8(3): e59054.

11. Running S, Zheng D, Hunt ERW (1993) A daily soil temperature model based on air temperature and precipitation for continental applications Climate research 2: 183-191.

12. Ahmad MF, Rasul G (2008) Prediction of soil temperature by air temperature; a case study for Faisalabad. Pakistan J Meteor 5(9): 252254.

13. Drees LR, Nordt LC, Wilding LC (2000) Pedogenic carbonate transformations. In leaching soil systems. Implications for global change 1: 43-64.

14. Santruckova H, Bird MI, Kalaschnikov YN, Grund M, Elhottova D, et al. (2003) Microbial characteristics of soils on a latitudinal transect in Siberia. Global change biology 9(7): 1106-1117.

15. Monokrousos N, Papatheodoroue EM, Stamou GP (2011) Under climatic change, soil microbial community and variables relating to $\mathrm{N}$-cycle are modulated by changes in the upper limit temperature. Global nest journal 13(4): 385-394.

16. Alexander M (1977) Introduction to soil microbiology. (2nd edn), Wiley, New York, USA.

17. Luo Y, Wan S, Hui D, Wallace LL (2001) Acclimation of soil respiration to warming in a tall grass prairie. Nature 413(6856): 622-625.

18. Dunbar J, Eichorst SA, Gallegos-Graves L, Silva S, Xie G (2008) Temperature response of wheat decomposition is more complex than the common approaches of most multi-pool models. J Soil biol Biochem 40: 2780-2786.

19. Dungait JAJ, Hopkins DW, Gregory AS, Whitmore AP (2012) Soil organic matter is governed by accessibility not recalcitrance. Global Change Biology 18(6): 1781-1796.

20. Henry HAL (2012) Soil extracellular enzyme dynamics in a changing climate. Soil Biology and Biochemistry 47: 53-59."

21. Schimel JP, Gulledge JM (1998) Microbial community structure and global trace gases. Global Change Biology 4(7): 745-758.

22. Satyam VS, Jayakumar (2012) Impact of forest fire on physical, chemical and biological properties of soil: A review. Proceedings of the International Academy of Ecology and Environmental Sciences 2(3): 168-176.

23. Brammer H, Brinkman R (1990) Chapter 12: Changes in soil resources in response to a gradually rising sea-level. Developments in Soil Science 20: 145-156.

24. Marion GM (1995) Freeze-thaw processes and soil chemistry. CRREL Special Report 95-12, p. 29.

25. Bolter M (1999) Consequenses of global warming on soil processes in Arctic regions, Polarforschung 66(1/2): 1-10. 
26. Monger HC (2010) Soil morphology adaptations to global warming in arid and semiarid ecosystems. 2010 19th world congress of soil science, soil solutions for a changing world, Brisbane, Australia.

27. Pregitzer KS, King JS (2005) Effects of soil temperature on nutrient uptake. Nutrient Acquisition by Plants 181: 117.

28. Paul EA, Clark FE (1996) Soil microbiology and biochemistry. (2nd edn), Academic Press Inc., San Diego, CA, USA.

29. Feddema JJ, Freire S (2001) Soil degradation, global warming and climate impacts. Climate Research 17(2): 209-216.
30. Balser TC, Gutknecht JL, Liang C (2010) How will climate change impact soil microbial communities? Soil Microbiology and Sustainable Crop Production, pp. 373-397.

31. Blume HP (2011) Global climate change effects on soils. Bulletin of national academy of science 5(2): 234

32. Lindsey C, Slaughter LC (2012) Soil microbial community responses to climate change: Result from temperate kentucky pasture. University of Kentucky, UK.

\section{Your next submission with Juniper Publishers will reach you the below assets}

- Quality Editorial service

- Swift Peer Review

- Reprints availability

- E-prints Service

- Manuscript Podcast for convenient understanding

- Global attainment for your research

- Manuscript accessibility in different formats ( Pdf, E-pub, Full Text, Audio)

- Unceasing customer service

Track the below URL for one-step submission https://juniperpublishers.com/online-submission.php 